only two days, while the limestone plateau on the approach to the Leonard Murray Mountains, the "cruel tract" of needle points and razor edges, which cost him eleven days arduous and painful travel, was crossed in fifteen minutes. No less significant was the accuracy with which it was possible to observe and distinguish the tracts and types of country described in the record of the original exploration. The account of the survey given by Mr. Lewis Lett (The Times, April 25) fully bears out Mr. Hides' description of the country as "a wonderland". In its isolation, it should prove the happy hunting ground of the future for the indomitable anthropologist.

\section{Mummification in Egypt}

AN interesting discovery, which it is thought may prove of considerable importance for the history of mummification in Egypt, is reported from Cairo. In a tomb near one of the pyramids opened by Prof. Selim Hassan, of the University of Cairo, has been found the body of a pregnant woman completely wrapped in bandages. She was the wife of Sechem Nefer, governor of a province under Chefren, the king of the Fourth Dynasty (2650 в.c.), who built the second pyramid at Gizeh. This, it is stated by the Cairo correspondent of The Times in the issue of April 21, is believed to be the oldest mummy known. In another tomb, that of Knum Baef, a son of Chefren, is a large white sarcophagus, not yet opened, upon which was found a gold necklace three feet long, with beading of carnelians, amethysts and turquoises, and ivory. and gold finger sheaths. A third tomb was found to contain the mummy of a man completely wrapped in bandages with the exception of the head. The earliest date at which mummification was practised in Egypt is at present somewhat obscure. It is possible that even so far back as the First Dynasty some attempt was made to ensure preservation of the body; and in the Second Dynasty the corrosion of the linen bandages in which the bodies are wrapped has been thought to be due to a practice of smearing the corpse with natron. Similar effects have been observed in burials of the Third and Fourth Dynasties. The full process, involving removal of the internal organs of the body, appears in the Fifth Dynasty. Details of the process applied to the preservation of the body of the wife of Sechem Nefer consequently will be of the greatest interest.

\section{Telephones for Use in Apartment Flats}

THE problem of installing a system of telephones in a block of flats differs in one important respect from a private telephone installation such as is used by a large business organisation privately owned. Flat dwellers, although resident in one building and indirectly employing a common staff, are independent members of the public. Hence in those countries where the provision of telephone communication is a monopoly either of the State or of companies acting under charter, the establishment of a system which enables tenants of flats to communicate with each other would be illegal. A telephone system for flats does not provide for intercommunication between tenants. The objects are to obtain immediate communication with the hall attendant and in some cases with the kitchen, garage and administrative office. In the Osram G.E.C. Bulletin of February, a telephone system is described in which the connexions are made to a 'reply panel' and not to a switchboard. It is designed to operate on the standard A.c. mains supply, a small power unit supplying direct current for speech and lamps so that no batteries are required. The 'buzzer' is also operated from the A.C. mains and hence the possibility of interference with radio sets in the building is removed. A picture is shown of a typical reply panel equipped for forty lines to flats. In addition, there are four service lines enabling the flat lines to be connected with all service lines, and ten 'tie lines' giving connexion when wanted to other panels. Each flat has a connecting plug associated with a calling lamp : there is also a buzzer on the panel giving an audible signal and thus relieving the attendant from the necessity of paying attention to the board except when his services are actually needed.

\section{Electrical Communication in Japan}

IN the February number of Nippon Electrical Engineering, published quarterly in English by the Institute of Telegraph and Telephone Engineers of Japan, the present status of Japanese broadcasting is discussed. It started ten years ago, and there are now 2,300,000 subscribers. Japan has a long and narrow configuration consisting of several islands the centres of which are covered with mountain ranges, so that conditions for broadcasting are very unfavourable. In this case it is much more effective to distribute a large number of low-power broadcasting stations over all the region than to erect a few high-power stations. The plans based upon a low-power many-station principle are being progressively realised. At the same time, in order to compete with other countries in international communications and to protect Japanese listeners against local interference, it has been decided to instal two high-power broadcasting stations, with 150 kilowatts of antenna power each, on the outskirts of Tokyo. It is computed that the field strength in Tokyo will be more than 200 millivolts per metre and will be ample to overcome any background of noise. All the equipment required for the stations can now be made locally. The Japan Broadcasting Corporation (B.C.J.) has built a special laboratory for studying radio technique. It has investigated apparatus for noise elimination and has made a direction finder for detecting the origin of noises. It is engaged in researches on television and is carrying out special experimental investigations on photoelectric tubes.

\section{Applications of Photo-Electric Cells}

AT a meeting of the Illuminating Engineering Society held on April 8, three papers were read on the uses and characteristics of photo-electric cells. R. C. Walker described the various types of light- 
sensitive cells. He pointed out that the problems to which it is intended to apply them are often mainly optical, electrical or mechanical. Audible warnings are sometimes given of the opening or closing of lift gates and announcing the record of automatic weighing machines. They will also be used on automatic telephone exchanges for announcing the correct time. Great demands on photo-cells will soon be made in television transmission. They are used for transmitting pictures by wire and radio. Other uses described were in counting objects, like cigarettes, passing along a conveyor, in giving warning when the web fractures on high-speed printing machines, for burglar alarms, smoke detection in factory chimneys, regulating the speed of escalators and the timing of sporting events. L. H. MeDermott described three different ways in which photo-cells have been used in connexion with problems of daylight illumination. The first was a relay to control the lighting of part of the National Portrait Gallery, the second was a device for the continuous recording of the amount of daylight illumination at Teddington and the third was used in the investigation now being carried out at the National Physical Laboratory into the lowest value of natural illumination which an office worker requires. In the third paper, W. H. B. Hall described an interesting device by which the automatic lighting and extinguishing of gas lamps at a London school was controlled by means of a photo-cell.

\section{Technical Exhibition at Glasgow}

A TECHNICAL exhibition was held in the Royal Technical College, Glasgow, on April 24-25. This exhibition was organised by the students of the College for two purposes : to provide the public with an opportunity of inspecting the College, and to provide past and present students and their friends with the opportunity of meeting one another socially. During these days each Department of the College was open for inspection, and was demonstrating the processes illustrating the various subjects studied in the College. In addition, the students obtained the co-operation of nearly forty outside firms, which sent numerous exhibits to supplement those on view in the Departments. The exhibition was officially opened by Mr. J. W. Peck, secretary of the Scottish Education Department; Mr. G. M. Smith being in the chair. The public was given the opportunity, for the first time, of viewing the wind tunnel recently installed in the Department of Mechanical Engineering for the purpose of aeronautical research, and also the distillation plant which was presented six months ago to the Technical Chemistry Department. Other exhibits of interest included a demonstration of television, glass-blowing, metal-spraying, spectrographic analysis, ultra-violet radiation, and many others that were of interest not only to the scientifically trained person, but also to the public. A Former Students' Association has been formed, and the inaugural meeting was held immediately after the opening ceremony, Mr. J. W. Peck being the chairman.

\section{Fire and Vegetation}

THrs very debatable subject has recently been discussed from a very statesmanlike point of view by a South African botanist, Prof. John F. V. Phillips (J. South African Bot., 2, Part 1). It is pointed out that whilst such characteristic native vegetation as the beautiful 'fijnbos' (the macchia or maquis of the south-west Cape) may be irretrievably damaged by fire, and whilst there is every reason for excluding fire definitely from the water conservation areas, yet on the other hand there is also clear evidence that controlled firing, carried out at the proper season, may encourage the subsequent establishment of better pasture grasses. Further, it may be argued that absence of fires, coupled with overstocking, has contributed to a marked increase in the prevalence of the woody overgrowth, especially of species of Acacia, which has led to a deterioration in the pastoral value of much tree-and-grass savanna. There is thus evidence of a need for protection of certain land from any type of fire treatment, whilst in other localities an early application of controlled fire treat. ment is probably desirable. Such a problem requires action by a responsible body, and Prof. Phillips suggests that the Minister of Agriculture and Forestry should act as chairman of a special Commission of Conservation which should formulate a policy and co-ordinate the functions of the various Government departments involved in the carrying out of this policy. Important legal and administrative problems are concerned. The matter is regarded as urgent by Prof. Phillips, who concludes that uncontrolled firing is costing South Africa untold millions and "creating for posterity a most serious state of affairs, which no amount of money ever would be capable of putting right".

\section{Seed Oats for Hill Districts}

Authough oats are still an important crop in Wales, a variety suitable to the particular conditions of the hill districts has been a long-felt want. Up to the present, Avena strigosa or Ceirch Llwyd has been grown on this type of land, and although it is essen. tially a variety for wet districts and poor land, it has the great disadvantage of not yielding a good sample, being heavily awned and consequently difficult to thresh. Breeding experiments with Avena strigosa carried out at the Welsh Plant Breeding Station have, however, resulted in the production of a new variety, Ceirch Llwyd Cwta S. 171, which is described in Leaflet Series S. No. 3, issued by the University College of Wales, Aberystwyth (price 1s.). The chief point of interest lies in the fact that it is awnless, but in addition it yields well or better than the older variety, the grain is heavier, the bushel weight higher and the protein content greater ; finally, it shows a resistance to both loose and covered smut. The amount of seed available for sowing this spring (1936) is about five tons, the wholesale price being 20s. per cwt. Co-operative societies, merchants and farmers interested in the new variety are asked to communicate with the Station at the earliest opportunity, as unless accurate estimation of the demand is obtained, 